\title{
Adrenergic intracerebroventricular stimulation affects progesterone concentration in the ovarian vein of the rat: participation of the superior ovarian nerve
}

\author{
M A De Bortoli, M H Garraza and L I Aguado \\ Laboratorio de Biología de la Reproducción (LABIR), Facultad de Química, Bioquímica y Farmacia, Universidad Nacional de San Luis, (5700) San Luis, \\ Argentina \\ (Requests for offprints should be addressed to L I Aguado, Universidad Nacional de San Luis, Chacabuco 917, (5700) San Luis, Argentina)
}

\begin{abstract}
The present study investigates the acute consequences of central adrenergic stimulation on the release of steroids from the ovary. The influence of the superior ovarian nerve (SON) and the relationship between the neural effect and peripheral LH levels were also examined.

The intracerebroventricular (i.c.v.) injection of $5 \mu \mathrm{g}$ epinephrine in SON-intact rats on day 1 of dioestrus (D1) increased progesterone levels in ovarian vein blood from 7 to $21 \mathrm{~min}$ after injection but the same injection in SON-intact rats on day 2 of dioestrus (D2) decreased progesterone levels in ovarian vein blood from 1 to $25 \mathrm{~min}$. A smaller dose $(0.5 \mu \mathrm{g})$ of epinephrine injected i.c.v. in SON-intact rats produced a decrease in progesterone levels in ovarian vein blood of shorter duration. In SON-transected (SONt) animals, $0.5 \mu \mathrm{g}$ epinephrine i.c.v. caused a smaller decrease in progesterone levels compared with SON-intact rats $(P<0 \cdot 05)$. On the other hand, in SON-intact rats on D2, the i.c.v. injection of $0.5 \mu \mathrm{g}$ epinephrine did not modify the peripheral $\mathrm{LH}$ levels during $25 \mathrm{~min}$, but $5 \mu \mathrm{g}$ epinephrine injected i.c.v. raised the peripheral LH level from the third minute after
\end{abstract}

injection $(P<0 \cdot 05)$. Oestradiol levels in the ovarian vein blood did not change after epinephrine i.c.v. injection in rats on D2.

To avoid any humoral influence, SONt and SONintact rats on D2 were injected i.c.v. with $5 \mu \mathrm{g}$ epinephrine or with vehicle, and 5 min later the ovaries were incubated in vitro with or without LH. Under these conditions, it was demonstrated that the previous injection of epinephrine in SON-intact rats resulted in a diminished release of progesterone from ovaries incubated with or without LH.

These results suggest that a central adrenergic stimulus increases progesterone release from the ovary on D1 and decreases it on D2. Also, this neural input would arrive at the ovary through the SON, and would condition the ovarian response to $\mathrm{LH}$ on D2. Ovarian progesterone changes could be attributed to signals coming from ganglionar neurons, which are affected by the central adrenergic stimulation.

Journal of Endocrinology (1998) 159, 61-68

\section{Introduction}

The rat ovary receives innervation from two main sources: the ovarian plexus nerve that travels along the ovarian artery, and the superior ovarian nerve (SON) which is associated with the suspensory ligament (Lawrence \& Burden 1980, Burden 1985). Microscopical studies show the SON fibres innervating thecal and interstitial cells, and also fibres coming from the ovarian plexus nerve associated with the vascular ovarian system (Baljet \& Drukker 1980, Burden 1985). Receptors of the beta adrenergic type have been characterized in ovarian membranes (Jordan 1981, Aguado et al. 1982) and have been found in different populations of ovarian cells (Condon \& Black 1976, Hsueh et al. 1984, Norjavaara et al. 1989). Additionally, the occupation of such receptors with adrenergic agonists produced progesterone and androgens release in the whole ovary in vitro (Aguado et al. 1982), and in luteal, granulosa and interstitial cells in culture (Condon \& Black 1976, Aguado \& Ojeda 1984a, Hsueh et al. 1984, Erickson et al. 1985, Norjavaara et al. 1989).

Transection of the SON $48 \mathrm{~h}$ previously results in a drop in the number of ovarian beta adrenergic receptors (Marchetti et al. 1987), while transection 7 days previously raises them (Aguado \& Ojeda 1984b). Additionally, electrical stimulation or the acute transection of the SON performed in live anaesthetized animals enhances or inhibits respectively the progesterone release from the ovary (Weiss et al. 1982, Aguado \& Ojeda 1984a).

The neurons from which the SON originate are located in the para- and prevertebral ganglia (Klein \& Burden 1988). Evidence of the neural connection between the 
central neurons and the ovary has been provided by electrical stimulation of central nuclei (Kawakami et al. 1972, 1981, Chiappas et al. 1977).

Although important advances have been made in this field, the role of the innervation in ovarian physiology remains obscure. In the present work, the effect of a central adrenergic stimulation on progesterone release from the ovary was studied in two cycle stages in which the corpus luteum is predominant in ovarian physiology. Also, the participation of the SON and the relationship between the neural effect and the level of luteinizing hormone $(\mathrm{LH})$ were analysed.

\section{Materials and Methods}

\section{Animals}

Virgin Holtzman strain female rats weighing 250-300 g were used in all the experiments. Animals had free access to food (Cargill SACI, Saladillo, Provincia de Buenos Aires, Argentina) and water. They were housed in cages under controlled light (lights on from 0700 to $1900 \mathrm{~h}$ ) and temperature $\left(24 \pm 2{ }^{\circ} \mathrm{C}\right)$.

\section{Ventricle cannulation}

Only rats showing at least two consecutive 4-day oestrous cycles were used. By means of a stereotaxic apparatus, a 22 -gauge stainless steel guide cannula was implanted chronically. The tip of the cannula was located within the right lateral cerebral ventricle $(4.0 \mathrm{~mm}$ ventral to the bregma and $1.5 \mathrm{~mm}$ lateral to the midline) and was later used for the intracerebroventricular (i.c.v.) microinjections. Ether was used as the anaesthetic, and the animals were maintained in individual boxes after the completion of the surgery. All rats were allowed to recover for 1 week after the stereotaxic surgery in order to recover their presurgical body weight. After that, on the following day 1 of dioestrus (D1), or day 2 of dioestrus (D2), the animals were used for the experimental procedures described below.

\section{Ovarian vein cannulation}

On the day of the experiment, shortly before i.c.v. injection, the left ovarian vein was cannulated as follows: a needle covered with a teflon tube (Abbocath-T 24-G) was passed through the left renal vein and $0.2 \mathrm{ml}$ heparin saline solution $(200 \mathrm{U} / \mathrm{ml}$ heparin in $0.9 \% \mathrm{NaCl}$; Abbot Lab, Sarmiento, Buenos Aires, Argentina) was injected. The needle was then removed and the left ovarian vein cannulated with the teflon tube, as described previously (Shaikh \& Shaikh 1975). The left uterine vein was ligated to avoid blood draining into the left ovarian vein.

All the vein cannulations and blood sample collections were carried out under chloral hydrate (Merck Química,
Roseti, Buenos Aires, Argentina) anaesthesia (35 mg/ $100 \mathrm{~g}$ body weight, i.p.).

\section{SON transection}

The procedure was described in previous reports (Lawrence \& Burden 1980, Aguado \& Ojeda 1984b). Briefly, before ovarian vein cannulation was completed, the suspensory ligament that contains the left SON was isolated by passing a suture thread under it. Cannulation of the ovarian vein was then completed, and the suspensory ligament was carefully lifted and severed not less than $1 \mathrm{~cm}$ from the ovary. In the sham-operated group, the procedure used was the same, but the SON was not transected.

\section{Jugular vein cannulation}

In another group of animals also carrying the ventricular cannula, the jugular vein was cannulated as previously described (Harms \& Ojeda 1974, Aguado \& Ojeda 1984c). After each blood extraction, samples were centrifuged and the plasma was frozen until LH determination. The original blood volume was recuperated by adding saline solution to the red cells and this was quickly returned to the animal through the jugular cannula.

\section{Ovarian incubations}

In the first experiment, two groups of rats were used: the sham-operated (SON-intact), and the SON transected (SONt). These two groups were injected i.c.v. with $5 \mu \mathrm{g}$ epinephrine, and 5-6 min later ovaries were removed, cleaned, and the oviducts were removed. The ovaries were then incubated in halves in a Dubnoff metabolic bath $\left(37^{\circ} \mathrm{C}\right.$, with $95 \% \mathrm{O}_{2}$ and $\left.5 \% \mathrm{CO}_{2}\right)$, while being continuously agitated.

When testing the effect of $\mathrm{LH}$, the ovaries were obtained only from animals with intact SON. Two groups were injected i.c.v. with $5 \mu \mathrm{l}$ vehicle or $5 \mu \mathrm{g}$ epinephrine respectively. The ovaries were incubated with ovine $\mathrm{LH}$ (50 $\mathrm{ng} / \mathrm{ml}$ incubation buffer).

The in vitro incubations were carried out using $2 \mathrm{ml}$ Krebs Ringer bicarbonate buffer, $\mathrm{pH} 7 \cdot 4$, as previously described (Selstam et al. 1976, Advis \& Ojeda 1978, Advis et al. 1979, Aguado et al. 1982, Lara et al. 1990a,b, Ferruz et al. 1991). To retain the in vivo neural influence received by the epinephrine i.c.v. injection, the preincubation period was shortened to $15 \mathrm{~min}$. The determinations of progesterone showed that the system becomes stable during this time (data not shown). Samples of the incubation buffer $(200 \mu \mathrm{l})$ were taken at $30,60,120$ and $180 \mathrm{~min}$. The results were expressed as ng progesterone/mg ovary.

\section{Experimental protocols}

The following experiments were performed on D1 between 1800 and $1900 \mathrm{~h}$, or on D2 between 1600 and 
$1800 \mathrm{~h}$. On D1, the experiments were performed after $1800 \mathrm{~h}$ in order to study the ovarian sensitivity to the neural inputs in coincidence with the progesterone rise described at this time (Uchida et al. 1969, Smith et al. 1975).

\section{Blood flow determination}

The blood flow was assessed in the ovarian vein, cannulated as described above, allowing the free flow of blood. Animals were divided into two groups: one group received no treatment (control) and the other group was injected i.c.v. with $5 \mu \mathrm{g}$ epinephrine at time zero. Blood samples were collected during $25 \mathrm{~min}$, once per min during the first $5 \mathrm{~min}$, and then every $2 \mathrm{~min}$. The volume of each sample was assessed by means of a set of calibrated tubes.

\section{Basal values of progesterone}

At the time of the experiments, basal values of progesterone in the ovarian vein blood were measured during $25 \mathrm{~min}$ following the i.c.v. injection of the vehicle $(5 \mu l$ ascorbic acid Sigma solution, $0.1 \mathrm{mg} / \mathrm{ml}$ in $0.9 \%$ saline) (Ba).

The effect of SON transection on the basal levels of progesterone in the ovarian vein was tested in blood samples collected after surgery (Bson). The means of the basal progesterone values obtained in each case were considered as $100 \%$ for future experiments.

\section{Intracerebroventricular injections}

After ovarian or jugular vein cannulation, the rats were subjected to i.c.v. administration of epinephrine under chloral hydrate anaesthesia.

Two doses, 5 or $0.5 \mu \mathrm{g}$, of epinephrine bitartrate (Sigma, St. Louis, MO, USA) were used in different groups of animals. The drug was dissolved in $5 \mu \mathrm{l}$ vehicle (ascorbic acid Sigma solution, $0.1 \mathrm{mg} / \mathrm{ml}$ in $0.9 \%$ saline). Each dose was injected slowly into the right lateral ventricle during $1 \mathrm{~min}$. The end of this injection was considered as time zero. After this, blood samples were collected from the ovarian vein for $25 \mathrm{~min}$ according to the schedule described for blood flow determination. After centrifugation, the plasma was collected and stored frozen until progesterone determination.

Jugular vein blood was collected in other animal groups at 3,10, 17 and $25 \mathrm{~min}$ after epinephrine i.c.v. injection. The volume of plasma necessary to measure LH (100 $\mu \mathrm{l})$ required the extraction of at least $0.5 \mathrm{ml}$ blood in each sample. The preservation of the physiological condition of the animals thus made it impossible to obtain samples every minute. Therefore, we chose the times at which major changes in progesterone concentration in the ovarian vein occurred. After centrifugation, the plasma was collected and stored frozen until LH assay.

\section{Hormone assays}

Progesterone and oestradiol were measured by RIA. Plasma was extracted as previously described (Jahn et al. 1995). The antisera were kindly provided by Dr R P Deis (Laboratorio de Reproducción y Lactancia, Mendoza, Argentina). The assays have previously been validated (Bussmann \& Deis 1979, Donoso 1988).

LH was measured by RIA, using a kit provided by the NIADDK of NIH (Dr Raiti, NIADDK Rat Pituitary Hormone Distribution Program), as recommended. The results were expressed in terms of LH-RP-2 NIH standard preparation.

\section{Data analysis}

Results are presented as means \pm S.E.M. in each group. Differences between groups were analysed with Student's $t$-test when two groups were compared. The analysis of the variance (ANOVA) followed by Duncan's multiple range test was used for several comparisons (Snedecor \& Cochran 1976). A value of $P<0.05$ was considered statistically significant.

\section{Results}

\section{Blood flow}

To detect if central adrenergic stimulation affects the ovarian vessels, the blood flow was measured under experimental conditions $(n=7)$. The volume of blood collected per minute from the ovarian vein of both control and epinephrine i.c.v. injected animals was analysed. When both groups were compared, no statistical differences could be detected. The values obtained were: control rats, $89 \cdot 4 \pm 8 \cdot 7 \mu \mathrm{l} / \mathrm{min}$; epinephrine i.c.v. injected rats, $83.9 \pm 9 \cdot 8 \mu \mathrm{l} / \mathrm{min}$.

Effect of epinephrine i.c.v. injection on ovarian vein progesterone levels on D1 (1800-1900 h)

Figure 1 (top panel) shows the levels of progesterone concentration in ovarian vein blood when vehicle or $5 \mu \mathrm{g}$ epinephrine was injected i.c.v. at time zero. When both groups of animals were compared at each time point the concentration of progesterone increased between 7 and $21 \mathrm{~min}(P<0.02$ at 7,9 and $17 \mathrm{~min} ; P<0.01$ at 11,13 and $15 \mathrm{~min} ; P<0 \cdot 05$ at 19 and $21 \mathrm{~min})$ in the rats injected with epinephrine.

\section{Effect of epinephrine i.c.v. injection on the ovarian vein progesterone levels on D2 (1600-1800 h)}

Figure 1 (bottom panel) shows the concentration of progesterone in ovarian vein blood when the vehicle or $5 \mu \mathrm{g}$ epinephrine was injected i.c.v. at time zero. When both groups of animals were compared, the progesterone 

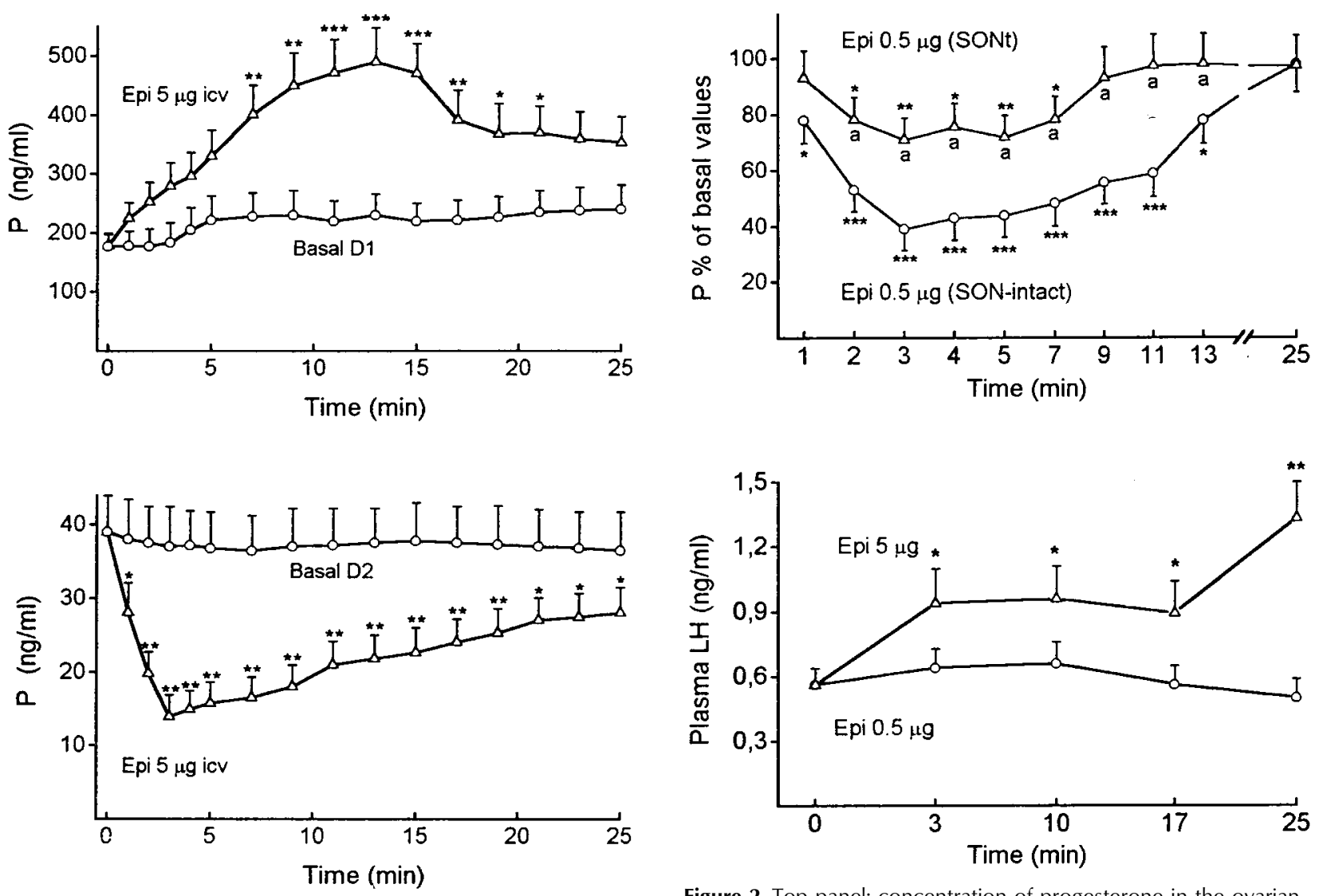

Figure 1 Concentration of progesterone in the ovarian vein: basal values after i.c.v. injection of vehicle $(\bigcirc)$ or $5 \mu$ g epinephrine (Epi) $(\triangle)$ to rats on dioestrus day 1 (D1) (top panel) and on dioestrus day 2 (D2) (bottom panel). The values represent the means \pm S.E.M. of five experiments. Top panel: ${ }^{*} P<0 \cdot 05,{ }^{* *} P<0 \cdot 02,{ }^{* *} P<0 \cdot 01$; bottom panel: ${ }^{*} P<0 \cdot 025,{ }^{*} P<0.01$ compared with basal values at the same time points.

values decreased between 1 and 25 min after the i.c.v. injection of epinephrine reaching minimal values at $3 \mathrm{~min}$ $(P<0 \cdot 025$ at 1, 21, 23 and 25 min; $P<0 \cdot 01$ between 2 and $19 \mathrm{~min})$.

Figure 2 (top panel, circles) shows the progesterone concentration in ovarian vein blood when SON-intact rats were injected i.c.v. with $0.5 \mu \mathrm{g}$ epinephrine. In these animals, the concentration of progesterone (as a percentage of $\mathrm{Ba}$, where $\mathrm{Ba}=37.5 \pm 1.62 \mathrm{ng}$ progesterone $/ \mathrm{ml}$ ) decreased between 1 and $13 \mathrm{~min}$ after i.c.v. injection $(P<0.05$ at 1 and $13 \mathrm{~min} ; P<0 \cdot 01$ between 2 and $11 \mathrm{~min})$. Basal progesterone concentrations were reached at $25 \mathrm{~min}$. In these animals the decrease in progesterone levels between 19 and $25 \mathrm{~min}$ was less than in animals injected i.c.v. with $5 \mu \mathrm{g}$ epinephrine $(P<0 \cdot 05)$.

In SON-transected (SONt) animals (Fig. 2, top panel, triangles), the values of progesterone (as a percentage of Bson, where Bson $=35 \cdot 0 \pm 1 \cdot 49 \mathrm{ng}$ progesterone $/ \mathrm{ml}$ ) decreased between 2 and $7 \mathrm{~min}(P<0 \cdot 05$ at 2,4 and

Figure 2 Top panel: concentration of progesterone in the ovarian vein after i.c.v. injection of $0.5 \mu \mathrm{g}$ epinephrine (Epi) to SON-intact $(\bigcirc)$ or to SONt $(\triangle)$ rats on D2. The values are the percentage of the basal value, $\mathrm{Ba}$, for $\mathrm{SON}$-intact rats and the percentage of the basal value, Bson, for SONt rats respectively, and represent the means \pm S.E.M. of five experiments. ${ }^{\star} P<0 \cdot 05,{ }^{*} P<0 \cdot 025,{ }^{*} * * P<0 \cdot 01$ (vs $\mathrm{Ba}$ or Bson respectively). ${ }^{\mathrm{a}} P<0.05$ for comparison of $\mathrm{SON}-$ intact vs SONt rats at each time point. Bottom panel: peripheral LH levels after i.c.v. injection of $0.5 \mu \mathrm{g}(\bigcirc)$ or $5 \mu \mathrm{g}(\triangle)$ epinephrine (Epi) to rats on D2. The values represent the means \pm S.E.M. of five experiments. ${ }^{*} P<0 \cdot 05,{ }^{*} P<0 \cdot 01$ comparing each value of both doses vs basal values.

$7 \mathrm{~min} ; P<0 \cdot 025$ at 3 and $5 \mathrm{~min}$ ) and basal levels were reached at $9 \mathrm{~min}$. When SON-intact and SONt rats injected i.c.v. with $0.5 \mu \mathrm{g}$ epinephrine were compared, the former group had lower progesterone values than the latter group $(P<0.05$ between 2 and $13 \mathrm{~min})$.

Effect of epinephrine i.c.v. injection on circulating $L H$ levels on D2 (1600-1800 h)

The concentrations of $\mathrm{LH}$ in jugular vein blood of rats (with intact SON) after 0.5 or $5 \mu \mathrm{g}$ epinephrine i.c.v. injection are shown in Fig. 2 (bottom panel). LH basal values were $0.56 \pm 0.08 \mathrm{ng} / \mathrm{ml}$. This experiment allows the study of LH levels when the central adrenergic stimulation affects progesterone secretion from the ovary in vivo. When the lower dose $(0 \cdot 5 \mu \mathrm{g})$ of epinephrine was 

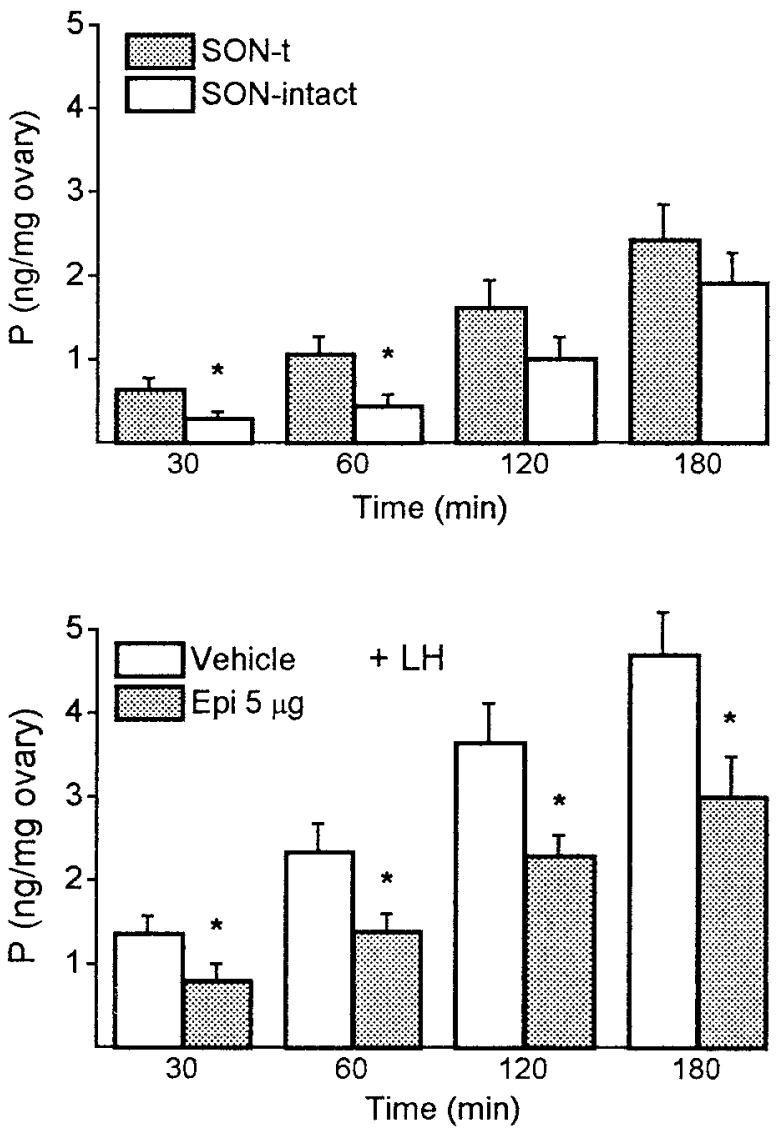

Figure 3 Top panel: concentration of progesterone released per $\mathrm{mg}$ ovary incubated after in vivo i.c.v. injection of epinephrine (Epi) to $\mathrm{SON}$-intact and $\mathrm{SON}$-transected rats on D2. The values represent the means \pm S.E.M. of five experiments. ${ }^{*} P<0 \cdot 05$ (SON-intact vs SONt rats). Bottom panel: concentration of progesterone released per mg ovary incubated with $\mathrm{LH}$, after in vivo i.c.v. injection of vehicle or epinephrine to $\mathrm{SON}$-intact rats on D2. The values represent the means \pm S.E.M. of five experiments. ${ }^{*} P<0 \cdot 05$ (Epi vs vehicle i.c.v. injected rats).

administered i.c.v. there was no difference in the circulating levels of LH compared with basal values. However, when the higher dose $(5 \mu \mathrm{g})$ of epinephrine was administered, the levels of $\mathrm{LH}$ increased from 3 to $25 \mathrm{~min}$ $(P<0 \cdot 05$ at 3,10 and $17 \mathrm{~min} ; P<0 \cdot 01$ at $25 \mathrm{~min})$.

In vitro ovarian incubation after the i.c.v. injection of epinephrine on D2 (1600-1800 h)

Ovaries were removed after i.c.v. injection of $5 \mu \mathrm{g}$ epinephrine and were incubated in vitro. The ovaries from sham-operated rats with intact SON (Fig. 3, top panel), released less progesterone than the ovaries from SONtransected animals. Progesterone release was different $(P<0 \cdot 05)$ between both groups at $30 \mathrm{~min}(0.65 \pm 0.12$ vs $0.30 \pm 0.07 \mathrm{ng} / \mathrm{mg}$ ovary $)$ and at $60 \mathrm{~min}(1.07 \pm 0.20 \mathrm{vs}$
$0 \cdot 45 \pm 0 \cdot 12 \mathrm{ng} / \mathrm{mg}$ ovary). No significant differences were observed at 120 and $180 \mathrm{~min}$.

In SON-intact animals, in which the central stimulus would arrive at the ovary, progesterone release was inhibited compared with rats previously SON-transected.

When ovaries from rats (all with intact SON) injected i.c.v. with vehicle or $5 \mu \mathrm{g}$ epinephrine were incubated in vitro with $\mathrm{LH}$, different amounts of progesterone were released (Fig. 3, bottom panel). Thus, the ovaries from animals injected i.c.v. with epinephrine released less progesterone than ovaries obtained from rats injected i.c.v. with vehicle $(P<0 \cdot 05$ at $30-180 \mathrm{~min})$.

Effect of epinephrine i.c.v. injection on oestradiol levels in the ovarian vein on D2 (1600-1800 h)

Ovarian granulosa and luteal cells possess beta adrenergic receptors but are not directly innervated. This experiment was conducted to study the effect of central adrenergic stimulation on ovarian oestradiol release, the principal steroid produced by granulosa cells.

After i.c.v. injection of $5 \mu \mathrm{g}$ epinephrine, oestradiol levels in the ovarian vein blood did not change significantly during $25 \mathrm{~min}$, compared with its own basal levels $(262 \pm 51 \mathrm{pg} / \mathrm{ml})$ on D2 $(n=7)$ (data not shown).

\section{Discussion}

Evidence has been provided supporting a neural connection between the central nervous system (CNS) and the ovary. Thus, electrical stimulation of some central nuclei affect progesterone and oestradiol release from the ovary (Kawakami et al. 1981) without any changes in gonadotrophins (Kawakami et al. 1972) or gonadotrophinreleasing hormone $(\mathrm{GnRH})$ release (Chiappas et al. 1977).

There are nervous fibres descending from the hypothalamus to the spinal cord that influence the peripheral neurons of the autonomic system (Saper et al. 1976). Descending projections of the hypothalamic paraventricular nucleus and the lateral hypothalamic area to sympathetic and vagal preganglionic neurons have been identified in the rat (Hosoya et al. 1991, Loewy 1991). In addition, sympathetic neurons reaching the ovary have been detected in para- and prevertebral ganglia by means of a retrograde tracer applied on the SON (Klein \& Burden 1988).

On the other hand, the presence of beta adrenergic receptors has been reported in the hypothalamus (Wilkinson et al. 1979, Wanaka et al. 1989) and in the hypothalamic GnRH neurons (Findell et al. 1993), and the challenge of these receptors by an agonist stimulates the release of GnRH in vitro (Martínez de la Escalera et al. 1992). The presence of alpha adrenergic receptors has also been reported in the hypothalamic paraventricular, supraoptic and arcuate nuclei (Pascual et al. 1992, Rosin et al. 1996). 
Furthermore, epinephrine injected i.c.v., travels from the cerebral spinal fluid (CSF) to the hypothalamus and produces an increase in circulating LH; it is more effective than norepinephrine during a period of $30 \mathrm{~min}$ (Krieg \& Sawyer 1976, Vijayan \& McCann 1978, Gallo \& Drouva 1979, Leung et al. 1982), which is why epinephrine was used in this study.

Considering all this evidence together, we can assume that epinephrine injected i.c.v. reaches the hypothalamus, impacting upon adrenergic receptors and affecting the autonomic function. Thus, we hypothesize that the central stimulation produced by epinephrine modifies ovarian function.

The effect of epinephrine on gonadotrophin release (McCann 1975, Krieg \& Sawyer 1976, Gallo \& Drouva 1979, Donoso 1988), allows the study of peripheral neuroendocrine integration between the hormones of the pituitary and the neural inputs to the ovary, which is the primary objective of this paper.

Release of progesterone was assessed because it appears to be the steroid most responsive to neural stimulation (Aguado et al. 1982, 1984a), and consequently two of the cycle stages in which the corpus luteum predominates in the ovary were selected. Thus the progesterone released by the ovary comes mainly from the corpus luteum and not from the granulosa cells in our experimental design.

In this animal preparation, changes in steroid concentration in the ovarian vein produced by i.c.v. injection of epinephrine, can be checked almost continuously during $25 \mathrm{~min}$, making the system appropriate for the study of neural effects. The blood collection times used agreed with the electrical registers in the median eminence and in the arcuate nucleus after catecholamine i.c.v. administration (Weiner et al. 1971, Krieg \& Sawyer 1976). These registers were affected immediately after injection and for up to $40 \mathrm{~min}$ (Sawyer 1979).

A point of discussion is the neural effect on ovarian blood flow. Here it has been demonstrated that, in the period studied, blood flow in the ovarian vein was not affected by i.c.v. epinephrine administration. Thus, it was assumed that changes in progesterone concentration in the ovarian vein were not due to variability in the blood volume draining the ovary. Additionally, the basal levels of progesterone in the ovarian vein in rats injected i.c.v. with vehicle remains unaffected on D2. Perfusing the ovary of rats with adrenergic agonists produces a fall of $30 \%$ in the blood flow rate but this does not modify progesterone release from the corpus luteum (Massa \& Bruce 1994). In our case, the fact that i.c.v. administration reversed the effect on progesterone release on D1 compared with D2 under the same experimental conditions, led us to think that the small but not significant changes in the blood flow did not influence steroid output.

When adrenergic agonists act directly on the ovary in the in vitro systems (Adashi \& Hsueh 1981, Aguado et al. 1982, Aguado \& Ojeda 1984b) or by systemic admin- istration (Bahr et al. 1974, Ojeda \& Aguado 1985), progesterone release always increases. In the present experiments, the drop in progesterone output observed on D2 led us to consider that the effect produced by the i.c.v. administration of epinephrine could not be accounted for by modifications in the circulating catecholamines levels.

Additionally, the fact that the release of progesterone was modified in opposed sense at D1 and D2 suggests that some other neurotransmitter distinct from norepinephrine is affecting the ovary in D2 (Dissen et al. 1993).

When a dose of $0.5 \mu \mathrm{g}$ epinephrine was injected i.c.v. into D2 animals, the fall in progesterone release observed in SON-transected animals was less pronounced and shorter than that observed in SON-intact rats. This finding supports the idea that SON participates, at least in part, in the neural pathway which links the CNS and the ovary. The remaining suppression of progesterone release that occurred in SON-transected animals could have been produced by the effect of epinephrine i.c.v. injection on the intact plexus ovarian nerve (Burden et al. 1981). Doses of 4 to $25 \mu \mathrm{g}$ norepinephrine or epinephrine administered i.c.v. usually produce an $\mathrm{LH}$ surge in peripheral blood after 10 to 20 min (Vijayan \& McCann 1978, Krieg \& Sawyer 1976, Rance et al. 1981, Wise et al. 1981, Donoso 1988). In this study, the smaller dose $(0 \cdot 5 \mu \mathrm{g})$ of epinephrine did not modify LH levels, but a larger amount of epinephrine $(5 \mu \mathrm{g})$ injected i.c.v., as by these authors, raised the gonadotrophin level from 3 to $25 \mathrm{~min}$ in the jugular vein blood. Perhaps this increase in LH masks a more pronounced neural effect on ovarian progesterone output on D2. Otherwise, it is possible that the enhanced progesterone release observed on D1 after i.c.v. epinephrine injection, was affected by a similar LH increase found on D2. Anyway, the progesterone peak that occurs on the afternoon of D1 in cyclic rats has been described as independent of gonadotrophin action (Uchida et al. 1969, Barraclough et al. 1971, Smith et al. 1975).

Considering that both doses of i.c.v. injected epinephrine inhibited the release of ovarian progesterone in rats on $\mathrm{D} 2$, we conclude that the neural effect is overwhelming the endocrine LH effect, and opens the possibility that the neural inputs could modulate ovarian sensitivity to the endocrine stimulations. In fact, an interrelationship between gonadotrophins and norepinephrine effects has been reported at the ovarian level (Aguado \& Ojeda 1984a, 1986, Ferruz et al. 1991). The clear effect found on progesterone release by epinephrine i.c.v. injection, however, contrasts with the lack of effect observed on oestradiol output. This finding agrees with previous results which suggest that oestradiol is modified by neural inputs only at pro-oestrus (Aguado \& Ojeda 1984c).

To take advantage of the pronounced effect on progesterone release shown after the $5 \mu \mathrm{g}$ epinephrine i.c.v. injection on D2, we carried out ovarian incubation shortly thereafter. This in vitro system has been widely validated previously (Hamberger \& Ahrén 1967, Selstam et al. 1976, 
Advis \& Ojeda 1978, Advis et al. 1979, Aguado et al. 1982, Lara et al. 1990a,b). In this condition, ovaries from rats previously injected i.c.v. with epinephrine were less responsive to the LH action in terms of progesterone release. If animals were previously SON transected, the inhibiting effect of epinephrine i.c.v. injection on ovarian progesterone output is less pronounced. These results confirm the neural nature of the effect shown on progesterone release; the idea of the participation of the SON also receives strong additional support. Experiments carried out by direct manipulation of the SON have suggested that the nerve maintains or even enhances progesterone output from the ovary (Weiss et al. 1982, Aguado \& Ojeda 1984c). However, as we have seen, adrenergic i.c.v. administration increases the progesterone release on D1 and inhibits it on D2. A similar pattern was observed when the celiac ganglion was stimulated by adrenergic agonists in an in vitro system (Z Sosa \& LI Aguado, unpublished observations). In view of this fact, we hypothesize that the i.c.v. injection of epinephrine primarily affects the central neurons which, in turn, stimulate other neurons that reach the ovary. The location of the former neurons remains unknown, but the location of the latter neurons could be in the paravertebral ganglia and especially the preaortic ganglia (Messenger et al. 1994). Of great interest is the fact that the effect produced in the ovary by central adrenergic stimulation is reversed between the D1 and D2 stage. This different action could be attributed to the central effect of the first small peak of progesterone occurring on D1 (Uchida et al. 1969), or to the rise in the oestradiol levels which starts on the afternoon of D1 (Shaikh \& Shaikh 1975). In fact, the influence of the CNS on the reproductive realm is modified by ovarian steroids in different cycle states and in ovariectomized estrogen-progesterone primed rats (Freeman 1994).

Finally, more investigation is needed to understand better the neural influence on the ovary, and particularly on the corpus luteum.

\section{Acknowledgements}

This work was supported by grant 3711/92 from CONICET (Consejo Nacional de Investigaciones Científicas y Técnicas, Argentina) and by grant 9302 from the Universidad Nacional de San Luis, Argentina. L I Aguado is a CONICET career scientist.

This work is part of the doctoral thesis of Miguel A De Bortoli.

\section{References}

Adashi YE \& Hsueh JA 1981 Stimulation of $\beta_{2}$-adrenergic responsiveness by follicle-stimulating hormone in rat granulosa cells in vitro and in vivo. Endocrinology 108 2170-2178.

Advis JP \& Ojeda SR 1978 Hyperprolactinemia-induced precocious puberty in the female rat: ovarian site of action. Endocrinology 103 924-935.
Advis JP, Andrews WW \& Ojeda SR 1979 Changes in ovarian steroidal and prostaglandin E responsiveness to gonadotropins during the onset of puberty in the female rat. Endocrinology 104 653-658.

Aguado LI \& Ojeda SR 1984a Prepubertal ovarian function is finely regulated by direct adrenergic influences. Role of the adrenergic innervation. Endocrinology 114 1845-1853.

Aguado LI \& Ojeda SR $1984 b$ Ovarian adrenergic nerves play a role in maintaining preovulatory steroid secretion. Endocrinology 114 1944-1946.

Aguado LI \& Ojeda SR 1984c Effect of selective removal of the adrenal medulla on female sexual development. Biology of Reproduction 31 605-618.

Aguado LI \& Ojeda SR 1986 Prepubertal rat ovary: hormonal modulation of $\beta$-adrenergic receptors and of progesterone response to adrenergic stimulation. Biology of Reproduction 34 45-50.

Aguado LI, Petrovic SL \& Ojeda SR 1982 Ovarian beta adrenergic receptors during the onset of puberty. Characterization, distribution and coupling to steroidogenic response. Endocrinology 110 $1124-1132$.

Bahr J, Kao L \& Nalbandov AV 1974 The role of catecholamines and nerves in ovulation. Biology of Reproduction 10 273-290.

Baljet B \& Drukker J 1980 The extrinsic innervation of pelvic organ in the female rat. Acta Anatomica 107 241-267.

Barraclough CA, Collu R, Massa R \& Martini L 1971 Temporal interrelationship between plasma $\mathrm{LH}$, ovarian secretion rates and peripheral plasma progestin concentration in the rat: effect of nembutal and exogenous gonadotropins. Endocrinology 88 1437-1447.

Burden HW 1985 The adrenergic innervation of mammalian ovaries. In Catecholamines as Hormone Regulators, vol 18, edn 165, pp 261-278. Eds N Ben-Jonathan, JM Bahr \& RI Weiner. New York: Raven Press.

Burden HW, Lawrence IE Jr, Louis TM \& Hodson CA 1981 Effects of abdominal vagotomy on the estrous cycle of the rat and the induction of pseudopregnancy. Neuroendocrinology 33 218-222.

Bussmann LE \& Deis RP 1979 Studies concerning the hormonal induction of lactogenesis by prostaglandin $\mathrm{F}_{2 \alpha}$ in pregnant rat. Journal of Steroid Biochemistry and Molecular Biology 11 1485-1489.

Condon WA \& Black DL 1976 Catecholamine-induced stimulation of progesterone by bovine corpus luteum in vitro. Biology of Reproduction 15 573-578.

Chiappas SA, Fink G \& Sherwood MM 1977 Immunoreactive luteinizing hormone-releasing factor (LHRF) in pituitary stalk plasma from female rats: effect of stimulating diencephalon, hippocampus and amygdala. Journal of Physiology 267 625-640.

Dissen GA, Dees WL \& Ojeda SR 1993 Neural and neurotrophic control of ovarian development. In The Ovary, pp 1-19. Eds EY Adashi \& CK Leung. New York: Raven Press.

Donoso AO 1988 Luteinizing hormone release induced by noradrenaline after administration of drugs that increase hypothalamic GABA levels. Acta Physiologica, Pharmacologica et Therapentica Latinoamerica 38 11-18.

Erickson GF, Magofin DA, Dyer CA \& Hofeditz C 1985 The ovarian androgen producing cell: a review of structure/function relationships. Endocrine Reviews 6 371-379.

Ferruz J, Barria A, Galleguillos X \& Lara HE 1991 Release of norepinephrine from the rat ovary: local modulation by gonadotropin. Biology of Reproduction 45 592-597.

Findell PR, Wong KH, Jackman JK \& Daniels DV 1993 $\beta_{1}$-adrenergic and dopamine $\left(D_{1}\right)$-receptors coupled to adenylyl cyclase activation in GT1 gonadotropin-releasing hormone neurosecretory cells. Endocrinology 132 682-688.

Freeman ME 1994 The neuroendocrine control of the ovarian cycle of the rat. In The Physiology of Reproduction, edn 2, pp 613-658. Eds E Knobil \& JD Neil. New York: Raven Press Ltd.

Gallo RV \& Drouva SV 1979 Effect of intra-ventricular infusion of catecholamines on luteinizing hormone release in ovariectomized and ovariectomized, steroid primed rats. Neuroendocrinology 29 149-162. 
Hamberger LA \& Ahrén KE 1967 Effects of gonadotrophins in vitro on glucose uptake and lactic acid production of ovaries from prepubertal and hypophysectomized rats. Endocrinology 81 93-100.

Harms PG \& Ojeda SR 1974 A rapid and simple procedure for chronic cannulation of the rat jugular vein. Journal of Applied Physiology 36 391-392.

Hosoya Y, Sugiura Y, Okado N, Loewy AD \& Kohno K 1991 Descending input from the hypothalamic paraventricular nucleus to sympathetic preganglionic neurons in the rat. Experimental Brain Research 85 10-20.

Hsueh AJW, Adashi EY, Jones PBC \& Welsh TH 1984 Hormonal regulation of the differentiation of cultured ovarian granulosa cells. Endocrine Reviews 5 76-127.

Jahn GA, Moya G, Jammes H \& Rosato RR 1995 Effect of chronic thyroid hormone treatment on cycling, ovulation, serum reproductive hormones and ovarian $\mathrm{LH}$ and prolactin receptors in rats. Endocrine 3 121-127.

Jordan AW 1981 Changes in ovarian beta adrenergic receptors during the estrus cycle of the rat. Biology of Reproduction 24 245-248.

Kawakami M, Seto K, Terasawa E \& Kimura F 1972 Role of the limbic-hypothalamic system in relation to ovulation and ovarian steroidogenesis. Medical Journal of Osaka University 23 57-75.

Kawakami M, Kubo K, Uemura T, Nagase M \& Hayashy R 1981 Involvement of ovarian innervation on steroid secretion. Endocrinology 109 136-145.

Klein C \& Burden HW 1988 Anatomical localization of afferent and postganglionic sympathetic neurons innervating the rat ovary. Neuroscience Letters 85 217-222.

Krieg R \& Sawyer CA 1976 Effect of intraventricular catecholamines on luteinizing hormone release in ovariectomized steroid primed rats. Endocrinology 99 411-419.

Lara HE, McDonald JK \& Ojeda SR 1990a Involvement of nerve growth factor in female sexual development. Endocrinology 126 364-375.

Lara HE, McDonald JK, Ahmed CE \& Ojeda SR $1990 b$ Guanethidinemediated destruction of ovarian sympathetic nerves disrupts ovarian development and function in rats. Endocrinology 127 2199-2209.

Lawrence IE Jr \& Burden HW 1980 The origin of the extrinsic adrenergic innervation to the rat ovary. Anatomical Record 196 51-59.

Leung P, Arendash G, Whitmoyer D, Gorski R \& Sawyer C 1982 Differential effects of central adrenoceptor agonists on LH release. Neuroendocrinology 34 207-214.

Loewy AD 1991 Forebrain nuclei involved in autonomic control. Progress in Brain Research 87 253-268.

McCann SM 1975 Effects of catecholamines on secretion of FSH, LH and prolactin by the adenohypophysis. In Basic Applications and Clinical Uses of Hypothalamic Hormones. Proceedings of the First International Symposium, Madrid. Excerpta Medica International Congress Series no. 374, pp 192-199. Amsterdam: Excerpta Medica.

Marchetti B, Cioni M, Badr M, Folléa N \& Pelletier G 1987 Ovarian adrenergic nerves directly participate in the control of LHRH and beta adrenergic receptors during puberty: a biochemical and autoradiographic study. Endocrinology 121 219-226.

Martínez de la Escalera G, Choi AL \& Weiner RI 1992 $\beta 1$-Adrenergic regulation of the GT1 gonadotropin releasing hormone $(\mathrm{GnRH})$ neuronal cell lines: stimulation of $\mathrm{GnRH}$ release via receptors positively coupled to adenylate cyclase. Endocrinology 131 1397-1402.

Massa HM \& Bruce NW 1994 Effects of noradrenaline on blood flow, progesterone secretion and consumption in the intact ovary of rats on day 16 of pregnancy. Journal of Reproduction and Fertility 101 605-610.

Messenger JP, Furness JB \& Truduing P 1994 Locations of postganglionic nerve cells whose axon nerves originate from prevertebral ganglia. Archives of Histology and Cytology 57 405-413.
Norjavaara E, Rosberg S, Gafvels M, Boberg BM \& Selstam G 1989 Beta adrenergic receptor concentration and subtype in the corpus luteum of the adult pseudopregnant rat. Journal of Reproduction and Fertility 86 567-575.

Ojeda SR \& Aguado LI 1985 Adrenergic control of the prepubertal ovary: involvement of local innervation and circulating catecholamines. In Catecholamines as Hormone Regulators, pp 293-310. Eds $\mathrm{N}$ Ben-Jonathan, JM Bahr \& RI Weiner. New York: Raven Press.

Pascual J, del Arco C, Gonzalez AM \& Pazos A 1992 Quantitative light microscopic autoradiographic localization of alpha2adrenoceptors in the human brain. Brain Research 585 116-127.

Rance N, Wise P, Selmanoff M \& Barraclough C 1981 Catecholamine turnover rates in discrete hypothalamic areas and associated changes in median eminence LHRH and serum gonadotropins on proestrus and diestrus day 1. Endocrinology 108 $1795-1802$.

Rosin DL, Talley RM, Lee A, Stornetta RL, Gailinn BD, Guyenet PG \& Lynch KR 1996 Distribution of alpha 2c-adrenergic receptor-like immunoreactivity in the rat central nervous system. Journal of Comparative Neurology 372 135-165.

Saper CB, Loewy AD, Swanson LW \& Cowan WM 1976 Direct hypothalamo-autonomic connections. Brain Research 117 305-316.

Sawyer HS 1979 The seventh Stevenson lecture: Brain amines and pituitary gonadotrophin secretion. Canadian Journal of Physiology and Pharmacology 57 667-680.

Selstam G, Rosberg S, Liljekvist J, Gronquist L, Perklev T \& Ahrén K 1976 Differences in action of LH and FSH on the formation of cyclic AMP in the prepubertal rat ovary. Acta Endocrinologica 81 150-164.

Shaikh AA \& Shaikh SA 1975 Adrenal and ovarian steroid secretion in the rat estrous cycle temporally related to gonadotropin and steroid levels found in peripheral plasma. Endocrinology 96 37-44.

Smith MS, Freeman ME \& Neill JD 1975 The control of progesterone secretion during the estrous cycle and early pseudopregnancy in the rat: prolactin, gonadotropin and steroid levels associated with rescue of the corpus luteum of pseudopregnancy. Endocrinology 96 219-226.

Snedecor GW \& Cochran WG 1976 Statistical Methods. Ames, Iowa: The Iowa State University Press.

Uchida K, Kadowaki M \& Miyake T 1969 Ovarian secretion of progesterone and 20 alpha-hydroxy pregn-4-en-3-one during rat estrous cycle in chronological relation to pituitary release of luteinizing hormone. Endocrinologia Japonica 16 227-237.

Vijayan E \& McCann SM 1978 Reevaluation of the role of catecholamines in control of gonadotropin and prolactin release. Neuroendocrinology 25 150-165.

Wanaka A, Malbon CC, Matsumoto M, Kamada T \& Tohyama M 1989 Presence of catecholaminergic axon-terminals containing beta-adrenergic receptor in the periventricular zone of the rat hypothalamus. Brain Research 479 190-193.

Weiner RI, Blake CA, Rubinstein L \& Sawyer CA 1971 Electrical activity of the hypothalamus: effects of intraventricular catecholamines. Science 171 411-412.

Weiss GK, Dail WG \& Ratner A 1982 Evidence for direct neural control of ovarian steroidogenesis in rats. Journal of Reproduction and Fertility 65 507-511.

Wilkinson M, Herdon H \& Wilson C 1979 Radioligand binding studies on hypothalamic noradrenergic receptors during estrous cycle or after steroid injection in ovariectomized rats. Brain Research 168 652-655.

Wise P, Rance N \& Barraclough C 1981 Effect of estradiol and progesterone on catecholamine turnover rates in discrete hypothalamic regions in ovariectomized rats. Endocrinology 108 2186-2193.

Received 13 August 1997

Revised manuscript received 5 January 1998

Accepted 19 May 1998 